\title{
Quality of power energy from wind power plant
}

\author{
F. Rajský ${ }^{1}$, M. P. Donsión ${ }^{2}$
}

\author{
${ }^{1}$ Department of Electrical Power Engineering and Environmental Engineering \\ Faculty of electrical engineering, The University of West Bohemia in Pilsen \\ Univerzitni 8; 30614 Pilsen; Czech Republic \\ phone: +420 776 8605232, fax:+420 37 7634301, e-mail: rajsky@kee.zcu.cz, \\ ${ }^{2}$ Electrical Engineering Department, Vigo University, Spain
}

Department of Electrical Engineering, University of Vigo, Campus of Lagoas Marcosende, 36310 Vigo (Spain), IEEE, EA4EPQ and AEDIE member, donsion@vigo.es

\begin{abstract}
The aim of this paper is to measure the quality of power coming from the wind power plant to the electrical distribution network. The quality of electrical energy includes many parameters but the main thesis target is to measure a harmonic frequency of current.

I used the program Matlab for the simulation of the connection between the wind power plant and the electrical network. I simulated startup of the wind turbine and changes of wind flowing. Obtained data were plotted on graphs which show harmonic frequencies of current based on these changes.
\end{abstract}

\section{Key words:}

Wind turbine, power quality, modeling of wind power plant, harmonic frequency

\section{Quality conditions}

While power quality is a convenient term for people, it is actually the quality of the voltage, rather than power or electric current that is an actual topic described by the term. Power is simply the flow of energy and the current demanded by a load is largely uncontrollable. However the relationship between the concepts of voltage quality and energy quality is unknown. [14]

No real life power feed will ever meet this ideal. It can deviate from it in the following ways:

- Variations in the peak or RMS voltage are both important to different types of equipment.

- When the RMS voltage exceeds the nominal voltage by 10 to $80 \%$ for 0.5 cycles to 1 minute, the event is called a swell.

A dip is the opposite situation: the RMS voltage is below the nominal voltage by 10 to $90 \%$ for 0.5 cycles to 1 minute

- Random or repetitive variations in the RMS voltage between 90 and $110 \%$ of nominal can produce a phenomenon known as flicker in lighting equipment. Flicker is the impression of unsteadiness of visual sensation induced by a light stimulus on the human eye.
- $\quad$ Abrupt, very brief increases in voltage, called impulses, or surges, generally caused by large inductive loads being turned off, or more severely by lightning.

- Under voltage occurs when the nominal voltage drops below $90 \%$ for more than 1 minute. The term brownout is an apt description for voltage drops somewhere between full power (bright lights) and a blackout.

- $\quad$ Over voltage occurs when the nominal voltage rises above $110 \%$ for more than one minute.

- $\quad$ Nonzero low-frequency impedance (when a load draws more power, the voltage drops).

- Nonzero high-frequency impedance (when a load demands a large amount of current, then stops demanding it suddenly, there will be a dip or spike in the voltage due to the inductances in the power supply line).

- $\quad$ Variations in the wave shape - usually described as harmonics.

\section{The practical measurement of power quality}

The graphs of active power during 24 hours are shown on figure 1 and 2 . I chose these two days because there was a high probability of mainly constant wind speed. But you can see many differences, e.g. the daily diagrams are complete different. For these reason it is impossible to make calculation exactly with wind energy based on daily diagram.

The summarizations values during 14 days are shown on figures 3 . The whole measurements took 30 days.

These graphs show:

- Non constant electric energy supply

- $\quad$ Non regulated electric energy

- Unpredictable electric energy supply

- The source of electric energy which need electric energy for own start

- The source of electric energy which need another source for regulation 


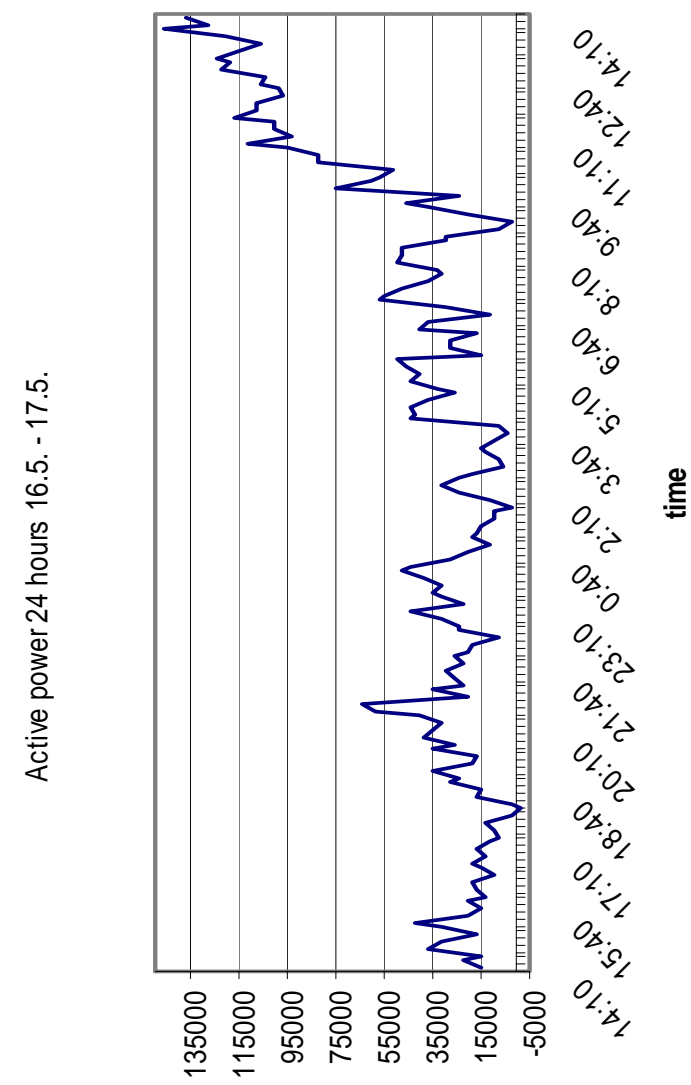

$[M] d$

Fig. 1 The Active power curve during 24 hours 16.5 .

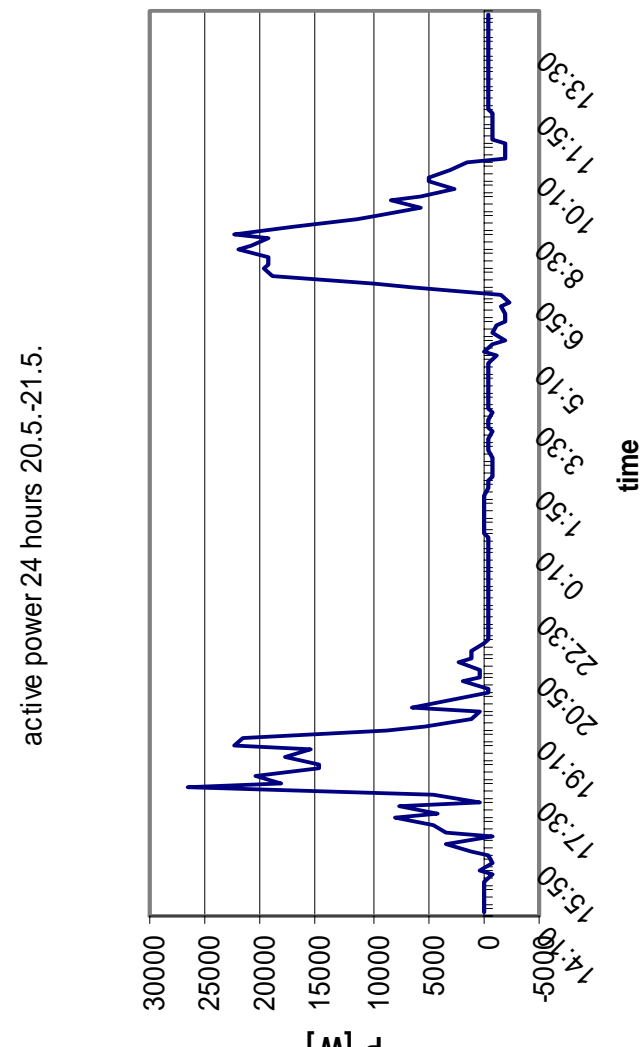

Fig. 2 TheActive power curve during 24 hours 20.5 .

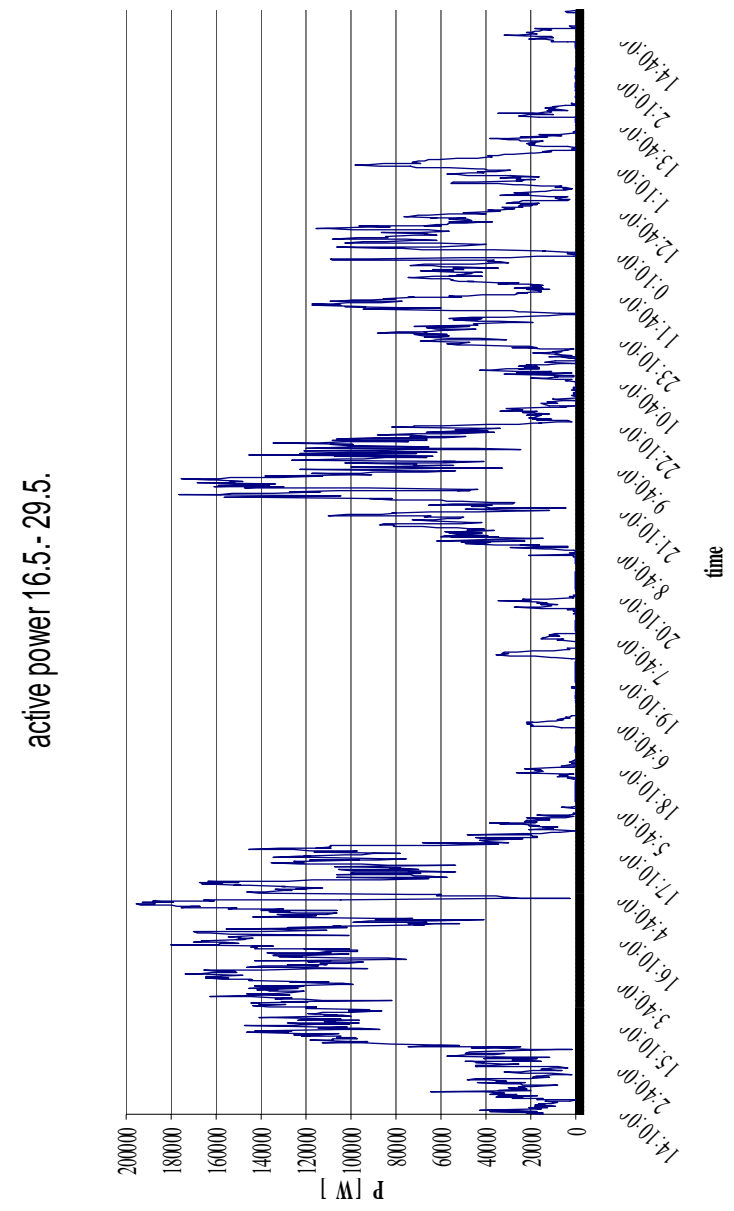

Fig. 3 The active power curve during 14 days

\section{Frequency}

The concept of energy quality enables the analyst to account for the previous indirect as well as direct requirements of energy flow. Such total energy flow requirements are analogous to cost in economic analysis. Because the calculation of those energy requirements is based on a set of processes operating at optimum energy efficiency, the energy quality calculations are assumed to identify the total energy cost that is in balance with maximum utility.

Ideally electric power would be supplied as a sin wave with the amplitude and frequency given by national standards UCTE (Union for the Co-ordination of Transmission of Electricity) $50 \mathrm{~Hz}$ or system specifications (in the case of a power feed not directly attached to the mains) with an impedance of zero ohms at all frequencies.

Harmonics become apparent when a distorted sinus curve is mathematically analyzed. Through Fourier analysis, an arbitrary periodic function can be divided into a number of sine waves. The example below shows that the distorted curve consists both of the fundamental frequency $(50 \mathrm{~Hz})$ and of super-imposed 5 th $(250 \mathrm{~Hz})$ and 7 th $(350 \mathrm{~Hz})$ harmonic frequencies.

A harmonic filter usually consists of a capacitor which is connected in series with impedance. The components are dimensioned to create a series resonance circuit for a 
required frequency. The harmonic filter works like a short circuit at one or more specified frequencies.

Real 24 hours measurement is shown in the first graph. During these 24 hours, wind flowing is low, starting increasing in the end of measuring interval. In this graph, curve of $50 \mathrm{~Hz}$ is not shown.

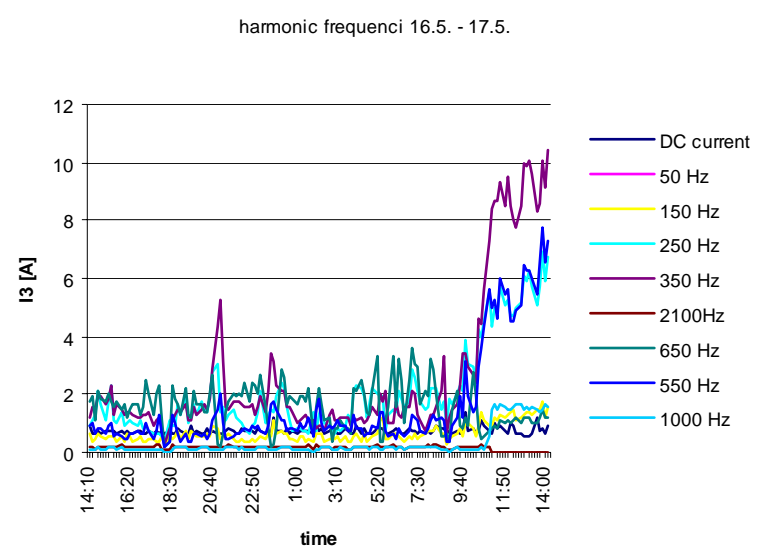

Fig. 4 Harmonic frequency curve during 24 hours

For the simulation I chose two different time and different situation. The situation with low and high flow wind is shown in these simulations. Each harmonic frequency is measured separately and for better evaluation it is shown in different scale.

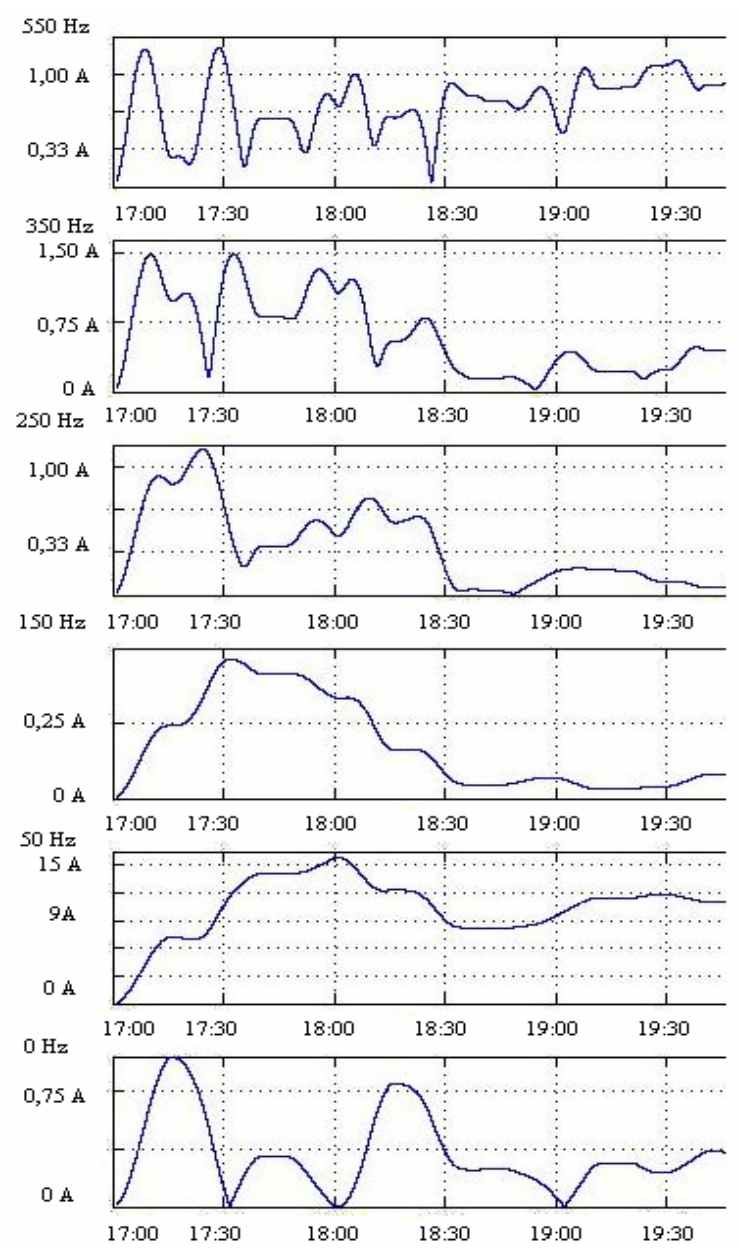

Fig. 5 Simulation of low wind flow

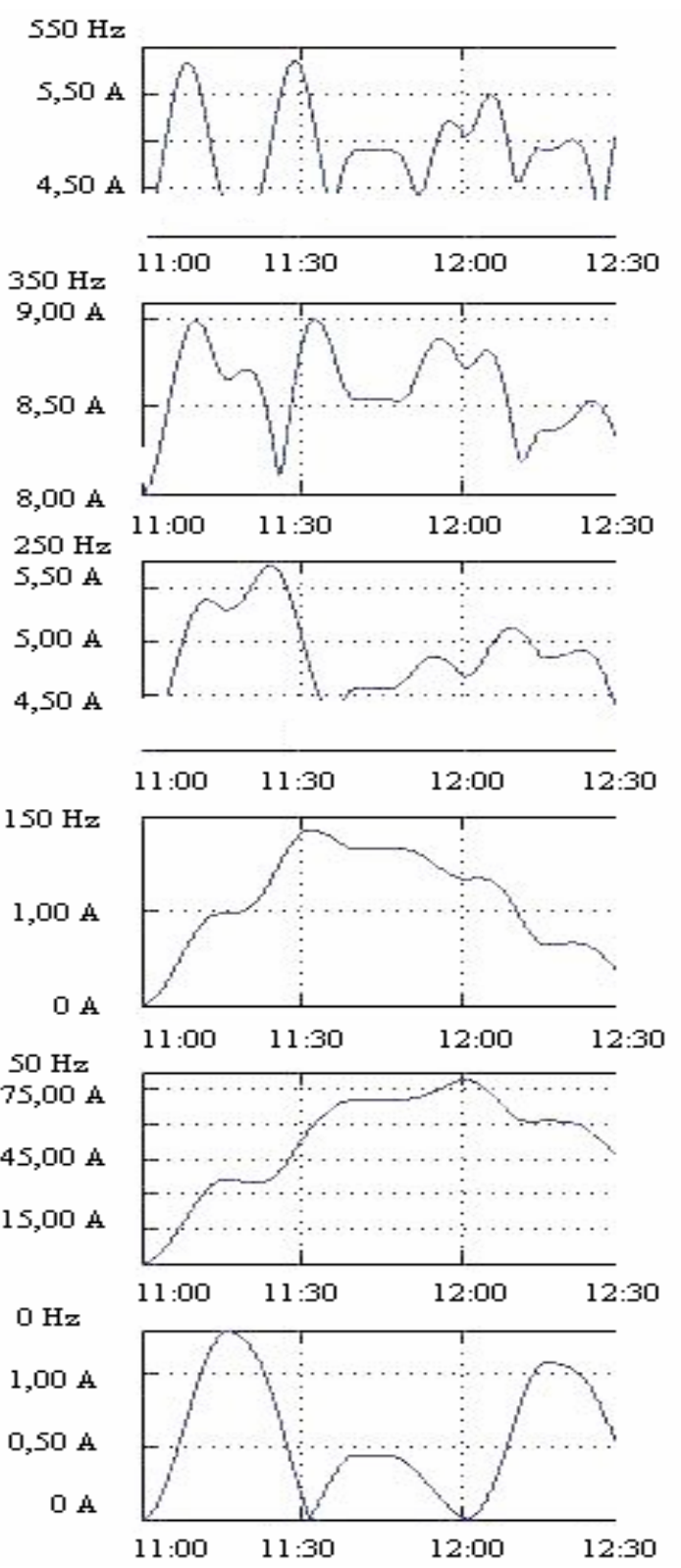

Fig. 6 Simulation of high wind flow

By comparison of these two graphs with the graph of measured values it can be concluded that the wind turbine simulation was correct.

The highest harmonic frequency 7 th has its maximum on $3 \%$ from $1 \mathrm{st}$ harmonic. Moreover, all harmonic together have maximum value $8 \%$ from 1 st harmonic frequency. The converter used in this wind power plant produce insignificantly harmonic frequency.

The modeled situations are similar to measured situations.

\section{Simulation by Mathlab}

In the figure 7 is shown model of wind turbine. The current, voltage measurement and regulation values are situate on right side. Input values like wind speed or wind power and wind trip are simulate in blue box. On the left side from wind generator are transformers, loads, distribution network with fault box in the middle and the last box on the left side is transmission network. 


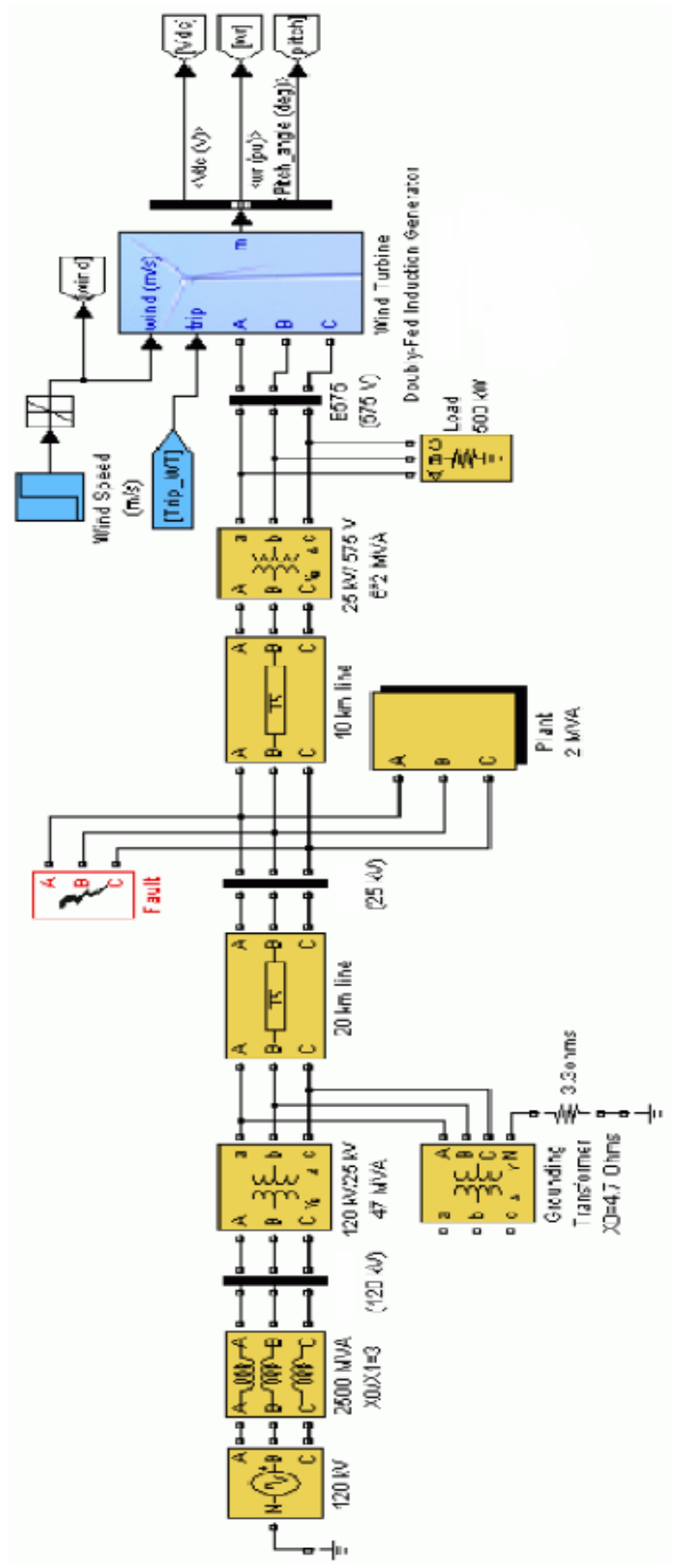

Fig. 7 Distribution network and wind turbine

\section{Simulation process}

Traditionally, the formal modeling of systems has been via a mathematical model, which attempts to find analytical solutions to problems which enable the prediction of the behavior of the system from a set of parameters and initial conditions.

While computer simulations can use some algorithms from purely mathematical models, computers can combine simulations with reality of actual events, such as generating input responses, simulating test subjects which are no longer present. Whereas the missing test subjects are modeled, the system they use could be the actual equipment, revealing performance limits or defects in long-term use by the simulating users.

Due to the mentioned reason it is possible only to recommend to create always a special model, which will represent a concrete surveyed physical effect and simulate some definite property namely according to the following progress on figure 8 .

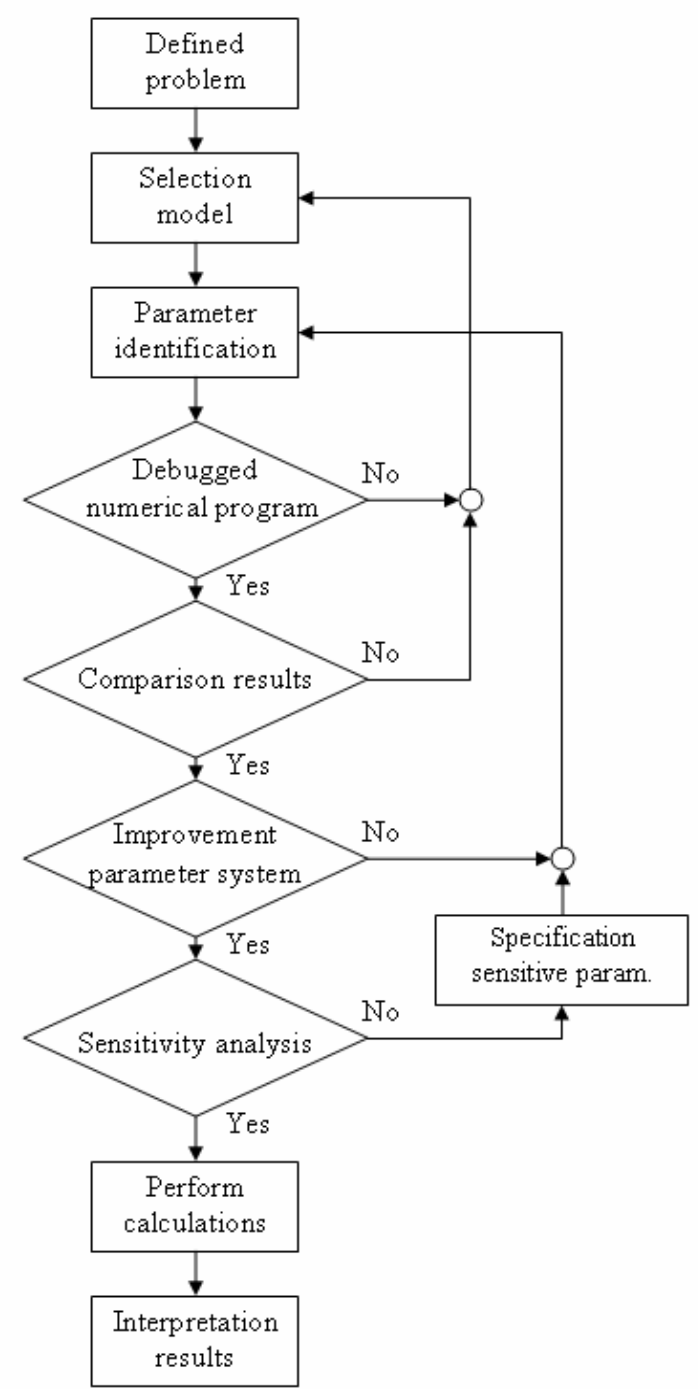

Fig. 8 Simulation process

\section{Conclusions}

The wind power is good source of renewable electrical energy. But problem related with this kind of energy is its instability, non constant producing power energy. During a few years device or appliance for constant producing this kind of power energy must be invented.

Wind turbines and solar panels are considered to be alternative sources of energy because they generate electric energy without producing $\mathrm{CO} 2$. Naturally, these sources depend on wind flow or solar activity therefore massive installation and utilization is complicated by connection these in-time and power unstable devices into the distribution network.

Solution can be found in intermediate stage which will be able to accumulate created energy into particular medium allowing constant output power supply and fast reaction on fluctuating power supply during daily energy peak. The system based on fuel cell technology can be regard as the intermediate step capable of chemical energy storage in reverse mode and energy delivery into electric network in power mode. 


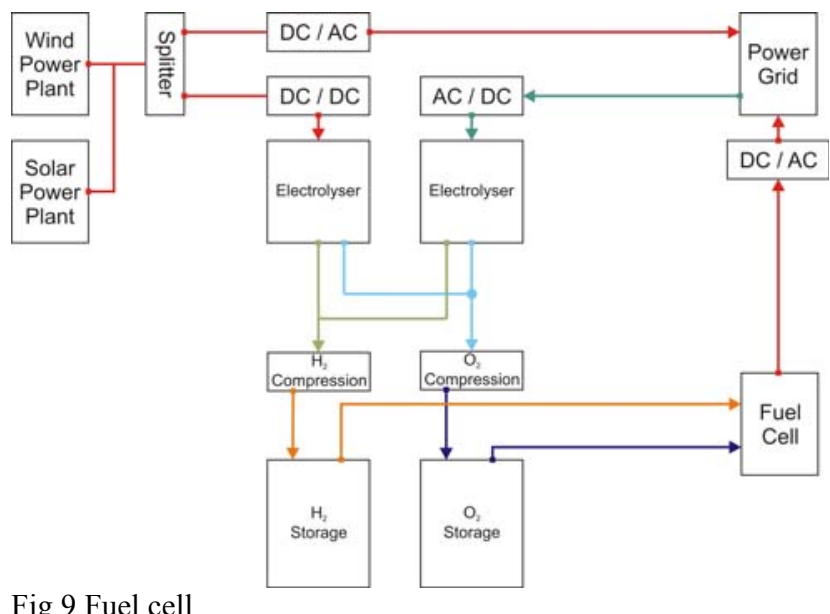

Fig.9 Fuel cell

Optimal method arose from experimental measurements and knowledge based on accessible research publication should be firstly analysed in the fuel cell field. Afterwards, the most fitting and affordable fuel cell will be used for general mathematical model description therefore numerical outputs can be compared with real values. This comparison should lead into correction equation implementation resulting in reaching the best accuracy. In next stage the model should be modified and extended by others parametric equations which allow further fuel cell technology description by input parameters. Another part should cover model transformation into numerical and consecutively into algorithm form to developed model simulation by using available software. Created simulation should be verified and compared with real values by employing eligible statistical methods.

\section{Acknowledgement}

The authors wish to thank the support from the Spanish "Ministerio de Ciencia y Tecnología", Research Project: ENE2007-6803-C04-01.

\section{References}

[1] T.Petrů - Modeling of wind turbines for power system studies- Göteborg, Sweden 2003

[2] M.P. Donsión - Análisis de la estabilidad de sistemas de potencia - Universidade de Santiago de Compostela 1993, ISBN: 84-7191-985-0

[0] W. M. Nicholas, J. Sanchez-Gasca, W. Price, R. W. Delmerico, "DYNAMIC MODELING OF GE 1.5 AND 3.6 MW WIND TURBINE-GENERATORS FOR STABILITY SIMULATIONS," GE Power Systéme Energy Consulting, IEEE WTG Modeling Panel, Session July 2003

[4] NOHÁČ, K.; NOHÁČOVÁ, L. Přehled současných možností počítačové simulace $\mathrm{v}$ elektroenergetice. In Česká energetika a elektrotechnika. 2004, č.3+4, s.2024, ISSN 1213-4171.

[5] S. Casoria, P. Brunelle, and G. Sybille, "Hysteresis Modeling in the MATLAB/Power System Blockset," Electrimacs 2002, École de technologie supérieure, Montreal, 2002
[6] F. Rajský - Modeling of wind power plant. In Environmental impacst of power industry 2008. Plzeň : Západočeská univerzita v Plzni, 2008. ISBN 978-80$7043-$

[7] F. Rajský - Preventing faults in a distribution network. In Environmental impacst of power industry 2007. Plzeň : Západočeská univerzita v Plzni, 2007. s. 72-75. ISBN 978-80-7043-541-0

[8] F. Rajský and M.P. Donsión - Comparison of transmission and distribution systems in the Czech Republic and Spain. In International Conference on Renewable Energy and Power Quality (ICREPQ'08) page 93,94 - Santander 2008, ISBN 978-84-611-9289-2 